\title{
Close-Ups and Fast Cuts: \\ Physiognomy, Choreography, and the Silhouette Films of Lotte Reiniger
}

"How Creation pauses and waits - water and air and earth and dust - all abuzz, animated, teeming, and surging!

(Johann Caspar Lavater, Physiognomische Fragmente) ${ }^{1}$

By invoking Genesis in the introduction to Essays on Physiognomy: For the Promotion of the Knowledge and the Love of Mankind (Physiognomische Fragmente zur Beförderung der Menschenkenntnis und Menschenliebe, 1775-1778), Swiss theologian Johann Caspar Lavater drew a brazen analogy between the creation of man and his own creation of a scientific method designed to introduce organizing principles into the study of physiognomy. He hoped to contrast a scene of untamed nature with the advent of divine order. And he did so through language that, for him, suggested an alarming degree of chaos: nature might be "animated, teeming, and surging " but equipped with the right tools, a man of reason might organize it. Lavater therefore conceived physiognomy as a counter to animation. He argued that a person's profile, traced on paper, provided a stable, legible exhibit from which character - namely moral fiber or weakness - could be openly discerned. The indecipherable "swarm" [Gewimmel] might in this way be stilled, examined, and ordered in the form of the silhouette. ${ }^{2}$ But the silhouette would not stay still. Shadow theater from Africa and East Asia had arrived in Europe and the craze for silhouette cutting coincided with a taste for ombres chinoises. These moving shadows blurred the edges of the stationary silhouette, inspiring artists and hobbyists to experiment with motion via a range of proto-cinematic

1 All translations my own. »Wie hier die Schöpfung stillsteht und wartet - - Wasser und Luft und Erde und Staub - Alles erfüllt, belebt, wimmelnd und wogen!" Johann Caspar Lavater: Physiognomische Fragmente zur Beförderung der Menschenkenntniß und Menschenliebe, vol. 1, Winterthur 1783, p. 1.

2 "Die ganze Schöpfung scheint zu trauern, zwecklos zu geniessen und nicht genossen zu werden! Wüste! Jedes Gewimmel!« (ibid.) 
devices. ${ }^{3}$ Pevauco's Living Silhouette, for example, was a simple optical toy made around 1900 in Germany. The card featured a partially detachable silhouette, whose shadow could be made to dance by sliding the figure back and forth in front of a light source. ${ }^{4}$ The advent of film pushed such optical tricks further, exploding the range of possibilities for animating both shadows and silhouettes. In Munich, Ludwig von Wich created a series of live-action silhouette films (circa 1917) while renowned German silhouette artist Ernst Moritz Engert tried his hand at designing shadow sequences for Shadows (1922) and Warning Shadows (Schatten - Eine nächtliche Halluzination, 1923). The dynamic between stasis and motion, problematized in the opening passages of Lavater's canonical text, continued to drive researches in film, and none more so than in the art of animation.

Lotte Reiniger had already created a number of short silhouette films before The Adventures of Prince Achmed (Die Abenteuer des Prinzen Achmed) garnered worldwide acclaim in 1926 (Abb. 1).

As the first feature-length animated film, the gorgeously designed fairy tale astounded audiences and critics alike. Silhouettes had moved before but never like this. Achmed was lauded as a "composite masterpiece of the shears, the brush, the camera and the trained technical fingers «. ${ }^{5}$ Reiniger was the first to animate silhouettes, ushering Lavater's physiognomic technique into film and initiating a genre whose influence endures today. ${ }^{6}$ While Lavater had championed stasis and order in the form of the silhouette, Reiniger

3 Germany was a locus of experimentation for shadow theater. The Schwabinger Schattenspiele was established in Munich in 1907. Its repertoire combined eastern shadow theater traditions with German folktales. See Peter Braun: Lotte Reiniger und das Schattentheater im frühen 20. Jahrhundert, in: Lotte Reiniger im Kontext der europäischen Medienavantgarde, ed. by Dorothee Kimmich and Evamarie Blattner, Tübingen 2011, pp. 36-51.

4 Four examples of Pevauco Living Silhouette (Patented) are on display at the Filmmuseum Düsseldorf. Each card features a different character: a dancing woman, a marching conductor, a woman playing tennis, and a man kicking a ball.

5 Herman George Scheffauer: Arabian Nights' Story Lives Again in Striking Two Dimensional Picture (1926). Newspaper clipping, Lotte Reiniger Nachlass, Stadtmuseum Tübingen, R 646.

6 Studies that explore the impact of Reiniger, or the silhouette and the shadow more broadly, include: Bernd Designer: Lotte Reinigers Langzeit-Effekt. Silhouettenfilm im aktuellen Kino/Lotte Reiniger's Longterm [sic] Effect: Silhouette Film in Present-Day Cinema, in: Animation und Avantgarde. Lotte Reiniger und der absolute Film/Animation and AvantGarde: Lotte Reiniger and Absolute Film, ed. by Evamarie Blattner, Bernd Designer, Matthias Knop, and Wiebke Ratzeburg, Tübingen 2015, pp. 101-116; Marion Ackermann: Schattenrisse Silhouetten und Cutouts, Ostfildern-Ruit 2001; Paolo Colombo (ed.): In Praise of Shadows, Milan/Dublin 2008. 


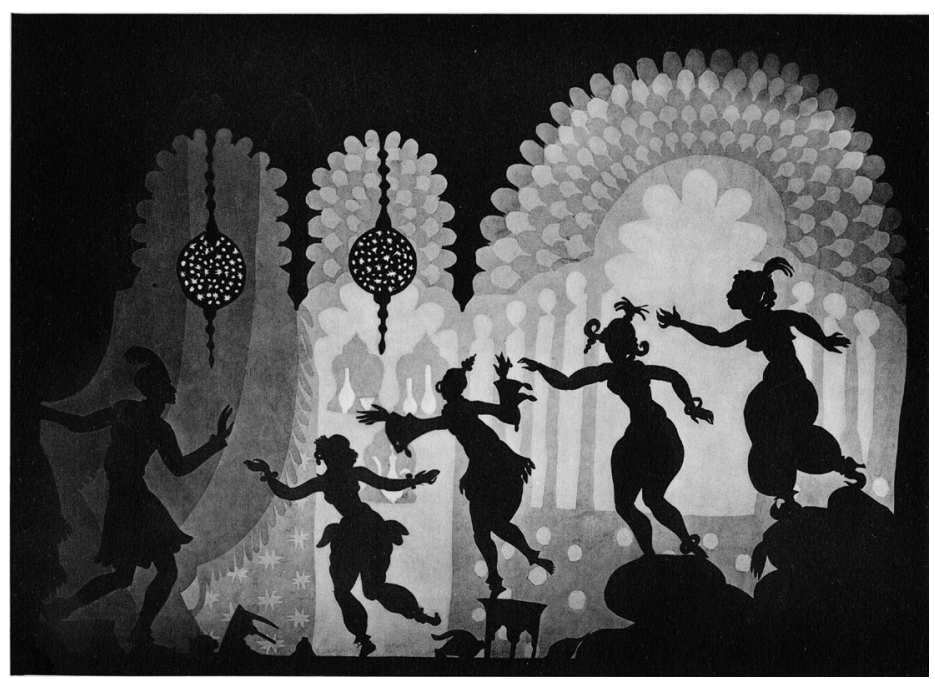

Abb. 1: Lotte Reiniger: The Adventures of Prince Achmed, 1926, film still. Stadtmuseum Tübingen, R 1998-4. (C) Christel Strobel, Agentur für Primrose Film Prod., Munich

explored how successive moments of stasis might be transformed into sequences of breathtaking motion. Her films raise the question: under what conditions was a science of stasis reconceived as an art of movement? After the wave of renewed interest in physiognomy sparked by Lavater began to ebb in scientific communities, its appeal as a philosophy based on graphic principles continued to find purchase in the literary and visual arts. ${ }^{7}$ Film, with its promise of photographic indexicality and its optimized technology for recording detail, meant that some film theorists found renewed urgency in the rhetoric of a philosophy devoted to judging internal character by external appearances. In what follows, I will examine the resurgence of interest in physiognomy in early film. Drawing on Reiniger's hand-crafted silhouettes and film theorist Béla Balázs' theses on physiognomy penned partially in response to them, I hope to reveal the ways in which the anatomy of the silhouette in motion challenged Lavater's line with the cut of the scissors.

7 For the impact of physiognomy on literature, film, and culture see Graeme Tytler: Physiognomy in the European Novel: Faces and Fortunes, Princeton 1982; Wolfgang Beilenhoff (ed.): Gesichtsdetektionen in den Medien des zwanzigsten Jahrhunderts, Siegen 2006; Melissa Percival/Graeme Tytler (ed.): Physiognomy in Profile: Lavater's Impact on European Culture, Newark 2005. 


\section{Lavater and the Physiognomic Line}

It is significant that the image associated most closely with Lavater's technique is a variation on a popular etching by his contemporary, J.R. Schellenberg, which demonstrates how to draw a silhouette using a specially designed machine (Abb. 2).

The machine, which had originally appeared in the first edition of the second volume of Lavater's Physiognomische Fragmente, was supposed to provide "the best method for drawing silhouettes" given the attendant difficulties of restless sitters and wobbly hands (Abb. 3). ${ }^{8}$

It allowed for the sharpest shadow to be cast on one side, while delivering the most accurate tracing conditions on the other. The resultant silhouette, according to Lavater, was to reveal the innermost characteristics of the sitter in question. Indeed, a range of machines for such enterprises had hit the market around the time of the publication of Physiognomische Fragmente, all equal to the task of, as one patent advertised, »Taking likenesses, by which the usual objections to the art, viz. time, trouble, and expence [sic], are entirely removed. $" 9$ The advent of these machines responded to the mass demand for silhouettes that swept Germany after the publication of Lavater's book and they capitalized on his claim that the tracing of silhouettes - unlike the painting of portraits - was an act so mechanical that high quality, objective results could be guaranteed to even the most amateur hobbyist. Schellenberg's etching may be seen as a response to this trend, furnishing the diagram from Lavater's book with the requisite actors and recording the artist's own preliminary findings in flowing script at the bottom of the image. Most importantly, Schellenberg's etching depicts the act of tracing a profile on paper. Although such silhouettes might later be cut out, the drawing would remain the $u r$-form. Lavater consistently referred to the silhouette tracer as the "drawer" [der Zeichner] and for the drawer he advocated precision: "Through a solar microscope the outline may be more sharply seen and accurately drawn. ${ }^{10}$ Lest there be confusion as to the importance of this drawing, Lavater declared: "In a silhouette there is but a line: no movement, no light, no color, no height, no depth; no eye, no ear - no nostril,

8 »Vorher noch nur ein Wort von der besten Art Silhouetten zu ziehen.« Johann Caspar Lavater: Physiognomische Fragmente, vol. 2, Winterthur 1784, p. 112.

9 Raphael Pinion: Limomachia, letterpress etching, 1780-1788. The British Museum, J,7.4.

10 »Durch das Sonnen Vergrößerungsglas lässt sich der Umriss noch ungleich schärfer sehen, und treflicher [sic] zeichnen."Johann Caspar Lavater: Physiognomische Fragmente, vol. 2, p. 113. 


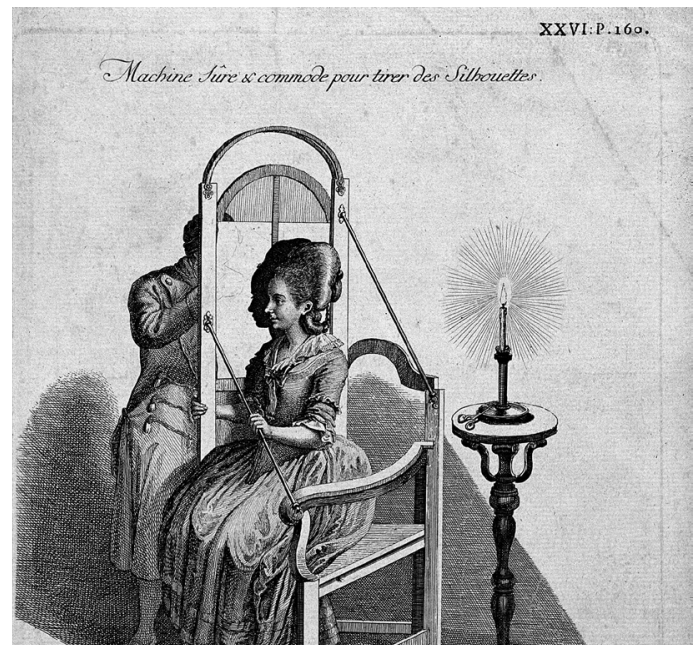

Abb. 2: J.R. Schellenberg: A man drawing the silhouette of a seated woman on translucent paper suspended in a frame and lit by a candle. 1783, etching. Image courtesy of Wellcome Library, no. $34363 \mathrm{i}$

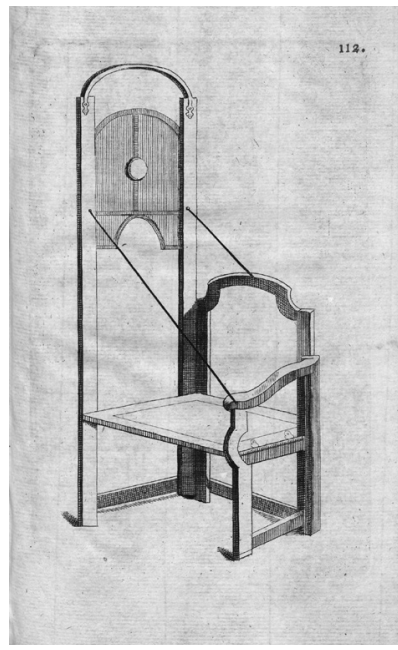

Abb. 3: J.C. Lavater: Physiognomische Fragmente, Bd. 2, 1784, p. 112 , etching. Image courtesy of Staatsbibliothek zu Berlin Preußischer Kulturbesitz

no cheek - only a bit of lip - however, how decidedly full of meaning it is! 11 Perhaps to emphasize this point, Physiognomische Fragmente was illustrated almost exclusively with delicate line drawings (Abb. 4).

When plates featuring seemingly solid silhouettes were included, closer examination actually reveals them to be etchings whose visible crosshatching once again inscribes shape with line (Abb. 5).

From the crispness of the shadow's contour, to the steady tracing of its edge, to the final analysis of its profile, line was of the utmost importance. The science of physiognomy was therefore dominated by the precision of line and only secondarily - if at all - by the cut of the scissors. Schellenberg's etching hews closely to this logic, privileging the act of drawing in the center of the page while a small pair of scissors rest discretely on the guéridon to the right. Scissors, on the other hand, were the decisive element in Reiniger's filmmaking process. Many of her filmmaking materials survive and an examination of her figures and scenery reveals that she drafted her silhouettes minimally,

11 »In einem Schattenriß ist nur eine Linie; keine Bewegung, kein Licht, keine Farbe, keine Höhe und Tiefe; kein Aug, kein Ohr- kein Nasloch, keine Wange - nur ein sehr kleiner Theil von der Lippe - und dennoch, wie entscheidend bedeutsam ist Er!« (ibid., p. 108) 


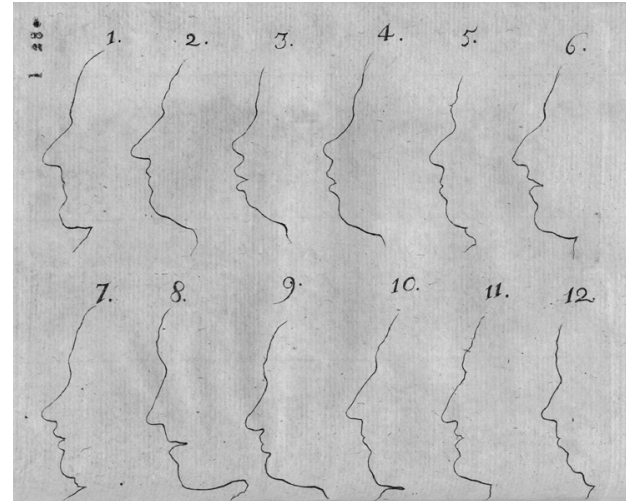

Abb. 4:J.C. Lavater: Physiognomische

Fragmente, Bd. 2, 1784, p. 280, etching. Image courtesy of Staatsbibliothek zu Berlin Preußischer Kulturbesitz

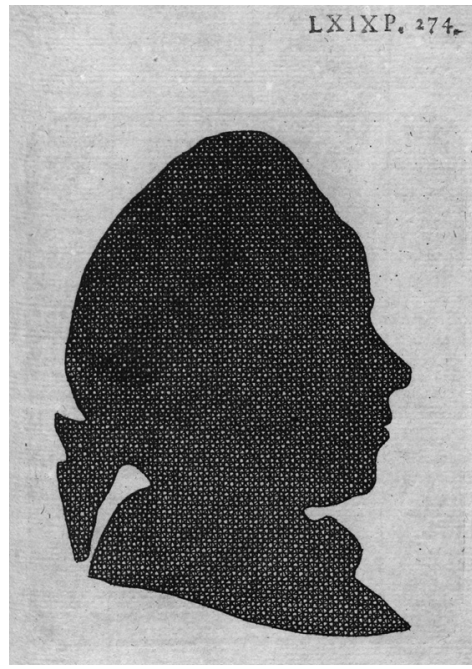

Abb. 5: J.C. Lavater: Physiognomische Fragmente, Bd. 3, 1787, LXIXP, S. 274, etching. Image courtesy of Staatsbibliothek zu Berlin Preußischer Kulturbesitz

sketching shapes loosely rather than tracing from cast shadows. ${ }^{12}$ Perhaps because her silhouettes were rarely based on real people her method of rendering them was gestural rather than studied. Protagonists such as Peri Banu or Prince Achmed were intuitive creations, dispatched with minimal sketching and maximum dexterity of the scissors. ${ }^{13}$ Such actors were cut from paper or rolled lead. In order to facilitate movement, various segments were cut separately and jointed together with twine (Abb. 6).

These silhouettes were then laid flat upon an animation table and shot frame by frame into motion. Reiniger's animation table was a horizontal structure of glass plates on which silhouettes, backgrounds, and special effects of sand, wax, and soap were lit from below and shot from above (Abb. 7).

12 See, for example, various figures from The Adventures of Prince Achmed (1926), Lotte Reiniger Nachlass, Stadtmuseum Tübingen, R 16531.

13 This is not to imply that her process was entirely intuitive. She employed careful planning at every stage, especially in regards to syncing movement with music. See Frauke Fitzner: Lotte Reiniger. Zur Rolle der Musik im frühen Film, Tübingen 2011. 


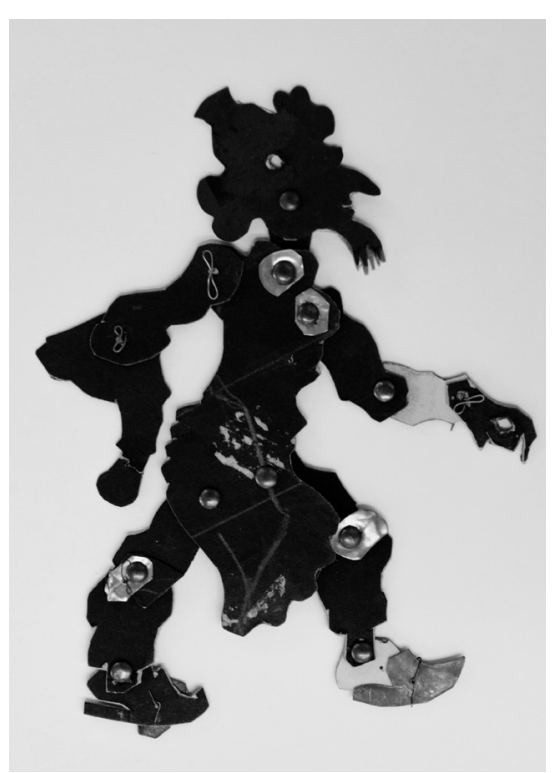

Abb. 6: Lotte Reiniger: Figure of the Magician, The Adventures of Prince Achmed, 1926, paper, lead. Stadtmuseum Tübingen, R. (C) VG Bild-Kunst, Bonn

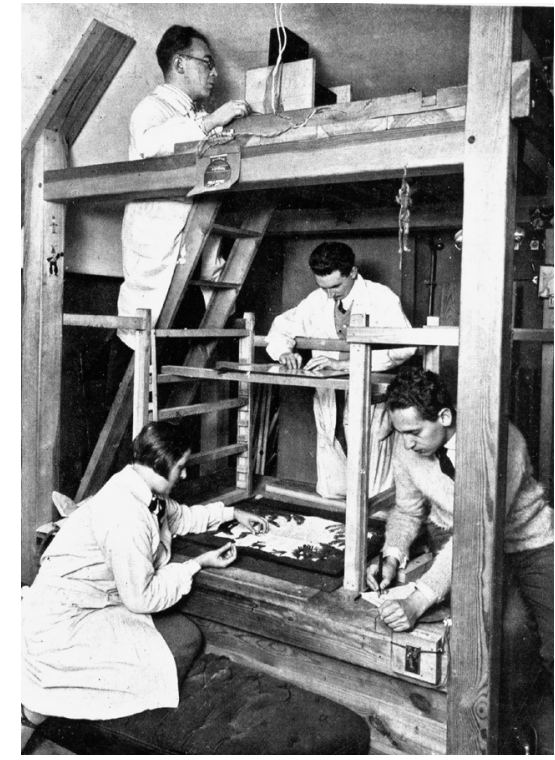

Abb. 7. Lotte Reinger's animation table. From left: Lotte Reiniger, Alexander Kardan, Walter Türk, Carl Koch. 1924, UFA Photo. Stadtmuseum Tübingen, Lotte Reiniger Nachlass. (C) VG Bild-Kunst, Bonn

From the cutting of the silhouettes to the cutting of the camera between each shot, the defining gesture of Reiniger's process was therefore the cut rather than the line. For Achmed, for example, 150,000 individual frames were ultimately arranged, shot, and cut into the final reels of film. That the cut should take on prominence by the time the silhouette had migrated to film is intriguing. After all, whether performed in-camera or on the editing table, film is an art comprised of cuts and Reiniger - like her counterparts in Dadaist, Surrealist and Constructivist circles - had begun to probe the cut for its artistic and ideological potential. ${ }^{14}$

14 Montage, in particular, was a heavily employed and hotly debated cutting technique. In 1926, Béla Balázs and Sergei Eisenstein had a bitter disagreement over montage, echoes of which clearly resound in Balázs' discussion of Reiniger's work. See Bern Stiegler: Reiniger vergisst die Schere nicht, in: Dorothee Kimmich/Evamarie Blattner (ed.): Lotte Reiniger im Kontext der europäischen Medienavantgarde, pp. 52-63. 


\section{Béla Balázs, Film Theory, and Physiognomy}

Remarking upon Lotte Reiniger's virtuoso facility for cutting silhouettes in The Spirit of Film (Der Geist des Films, 1930), film theorist Béla Balázs observed that, in Reiniger's work, "[t]he power that transforms a silhouette is neither psychology nor the camera lens, but simply a pair of scissors «. ${ }^{15}$ Balázs was a utopian Marxist, who, in part, evaluated the success of a film by how poetically it communicated an ideological point of view. ${ }^{16}$ While he eschewed what he considered to be lax formalism in the geometrically abstract films of artists like Hans Richter or Viking Eggeling, he delighted in Reiniger's figurative, narrative work. In a chapter devoted to experimental filmmaking titled "Absolute Film", Balázs singled out Reiniger for her pioneering animations. Her appeal lay in the fact that while she borrowed seemingly familiar forms, she remade them entirely anew for film. Moreover, Reiniger's work combined fairy tales - a literary genre rife with allegories of class struggle - with sheer originality. Her films were not mere literary adaptations that enlisted pre-existing objects (dolls or marionettes) to narrate a story. Rather, Balázs argued that they were filmic creations in which the story arose from the silhouettes themselves: »For inventiveness begins here not with the story, but with the visual appearance of the filmic figures. What determines a fairy tale is not the plot but the shape of the figures in it. The visual imagination is these films' driving force. «17 As such, Reiniger's films achieved the full potential of the trick film, whose production of a seemingly fantastical world actually mirrored the real mechanisms at play in the human psyche. Because Absolute Film sought not to reproduce external reality for the camera to record but to construct internal reality in partnership with the camera, Balázs concluded that Reiniger's silhouette films were »the very essence of absolute film «. ${ }^{18}$ Reiniger therefore held a prominent place in Balázs' influential treatise on film, whose larger thesis, outlined six years earlier in Visible Man (Der sichtbare Mensch, 1924), celebrated the cinema as an advancement in physiognomy. Film, he argued, was uniquely positioned

15 Béla Balázs: The Spirit of Film, in: Béla Balázs Early Film Theory: Visible Man and The Spirit of Film, ed. by Erica Carter, New York 2010, pp. 91-211, here p. 170.

16 Gertrud Koch has questioned the accuracy of labeling Balázs a Marxist theorist. She points out that the Frankfurt School theorists were wary of him, rarely citing his work although they were certainly influenced by it. Gertrud Koch/Miriam Hansen: Béla Balázs: The Physiognomy of Things, in: New German Critique 40 (Winter 1987), pp. 167-177.

Ibid. 
to deliver meditations on the inner workings of individuals, cultures, and even nature by virtue of its technology. Whether realistic or expressionistic, the ability of the camera to bring details into focus meant that, "[i]n film, everything internal becomes visible in something external; it follows that everything external testifies to an internal reality .19

Balázs' embrace of the term sphysiognomy has meant that Visible Man and The Spirit of Film are often understood as a revival of Lavater's Enlightenment era ideas in the modern medium of film. In fact, it would be more accurate to say that it was Balázs' romanticizing of film that modernized Lavater's physiognomy. For it was Goethe, not Lavater, whom Balázs acknowledged as an intellectual forbearer in his formulation of physiognomy. The difference is telling. Goethe had initially supported Lavater's work and even collaborated with him, particularly in the first two volumes of Physiognomische Fragmente, but the two had parted ways due to a disagreement over the nature of form [Gestalt]. In a section titled "Goethe on Film«, Balázs quotes Goethe's contribution to Lavater's book:

What is the human exterior? Certainly not a man's naked body or involuntary gestures that point to his inner energies and their actions! Status, habit, possessions, clothing - all these modify and conceal him. To penetrate all these cloaks and arrive at his innermost nature, to discover fixed points that would enable us to infer his essence even among all these factors, appears extremely difficult, almost impossible. ${ }^{20}$

Already discernable in this passage is Goethe's skepticism concerning the durability of external appearances. Could character be extrapolated solely from a nose or a chin? According to Lavater, the answer was essentially, yes. Physiognomy's object was static and enduring: »We must be able to distinguish clearly between the solid and the mobile, between the permanent and the contingent. ${ }^{21}$ While Lavater aimed to capture fully formed eternal truths by tracing the profile in stasis, Goethe developed a theory

19 Béla Balázs: Visible Man, in: Béla Balázs Early Film Theory, pp. 1-87, here p. 29.

20 Johann Wolfgang von Goethe: Von der Physiognomik überhaupt, in: ders.: Gedenkausgabe der Werke, Briefe und Gespräche, ed. by Ernst Beutler, vol. 17, Zürich 1952, p. 439. Quoted in: Béla Balázs: Visible Man, p. 29.

21 Johann Caspar Lavater: Physiognomische Fragmente, vol. 1, p. 13: „Wir müssen das Feste von dem Weichen, das Haftende von dem Zufälligen wohl unterscheiden." Quoted and translated in: Michael Gamper: »Er lässt sich nicht lessen«: Physiognomy and the City, in: Physiognomy in Profile: Lavater's Impact on European Culture, ed. by Melissa Percival and Graeme Tytler, Newark 2005, pp. 150-160, here p. 158. 
that allowed for flexibility. For Goethe, forms were not static and complete, but rather constantly shifting in an eternal impulse toward an unattainable whole. That Balázs quotes Goethe and not Lavater, is significant, for it is precisely this element of animation that most interested Balázs. After quoting Goethe, Balázs remarks: "Nothing needs adding to this. Except to say that the physiognomy of a face can be varied at any moment by the play of expressions, which converts the general type into a particular character. «22 For Balázs, then, the connection to Goethe introduces the key difference between Lavater's philosophy and Balázs' formulation of physiognomy for film: movement.

For Balázs, film is the physiognomic medium par excellence for it sets the face in motion. By marrying external appearances with interior emotional states, "film presents not just a once-and for-all rigid physiognomy, but a mysterious play of expressions «. ${ }^{23}$ It does so principally through the closeup shot, an in-camera function made possible by zoom technology. "The close-up«, declares Balázs, »is the poetry of the cinema. ${ }^{24}$ To this end, he devotes rapturous passages to close-ups of Asta Nielsen and Lillian Gish, Pola Negri and Emil Jannings. Far from descriptions of static frames, these vivid analyses follow each face as it undergoes an emotional transformation in which Balázs discerns "not just the individual states of the soul but also the mysterious process of development itself «. ${ }^{25} \mathrm{He}$ logs the tempo of expressions that flicker across their faces and marvels at the authenticity of emotion revealed through the rhythm of their acting. In each, Balázs makes the case for an expanded conception of physiognomy away from stasis towards movement.

Insofar as Balázs' filmic physiognomy concerns the close-up, his admiration of Reiniger might seem misplaced. After all, her silhouettes neither expose the inner nature of their sitters (there are no sitters), nor reveal a complex series of emotions in close-up (there are hardly any facial features). More to the point, there are not even - technically speaking - any close-ups. Techniques used in film to adjust camera distance may have the same effect but were achieved differently in Reiniger's stop-motion animation. Because the camera remained stationary, the manipulation of scale occurred at the level of the silhouettes themselves. In order to mimic the zoom of the camera,

22 Béla Balázs: Visible Man, p. 29.

23 Ibid., p. 46.

24 Ibid., p. 41.

25 Ibid., p. 34. 
Reiniger shot a series of frames in which progressively larger heads were subbed in for smaller ones. Increasing scale and a proliferating number of cutouts therefore subsume the role of spatial maneuvering on the part of the lens. In this case, the cut - and not the camera - remains the arbiter of detail. Movement is therefore simulated through editing (cutting) rather than performed by the camera or by the facial muscles of actors. Indeed, Reiniger had this to say on the subject of the close-up: "[A] close-up intensifies film action by focusing attention on the dramatic key-point, and this effect is obtained by the utmost economy of action within the close-up itself. « 26 If the close-up heralds facial mobility for Balázs but signals stasis for Reiniger, then we appear to be confronted by two opposing models of filmic physiognomy. However, Balázs' conception of physiognomy is as much about bodily gesture as it is about facial expression. He is quick to point out that, "[w] hen an actor has no lines to speak, his entire body becomes a homogeneous expressive space and every crease in his clothes takes on the same expressive significance as a wrinkle in his face ${ }^{27}$ Taking the analogy one step further, Balázs insists that facial features should, in fact, "not compete with the living movement of gestures", for in the communication of internal emotional states, gesture is, in fact, the stronger vector. ${ }^{28}$ Ultimately, then, the close-up for Balázs is a mere technical device. It may reveal emotional progression on film but its mechanism is incidental to its effect. Understood this way, the cut may be cast as Reiniger's answer to the zoom, enabling her silhouettes to convey emotion through the careful choreography of gesture.

\section{Lotte Reiniger: Choreographing the Cut}

As an animation artist, Lotte Reiniger devoted herself to the study of movement. Through her writings and films, she explored the subtleties of theatrical versus filmic choreography, finding in film a field of expanded possibilities for motion: »The real sensation for me has always been - and will always be - the discovery of various possibilities of screen rhythm which,

\footnotetext{
26 Lotte Reiniger: Film as Ballet, in: Life \& Letters Today 14/3 (Spring 1936), pp. 157-163. Reprinted in: The Red Velvet Seat: Women's Writings on the Cinema: The First Fifty Years, ed. by Antonia Lant, London/New York 2006, pp. 166-172, here p. 171.

28 Ibid., p. 29.
} 
to my experience, is the most essential part of film art. « $^{29}$ More precisely, she was fascinated by dance. Reiniger had trained in dance and theater at the Charlottenburg Waldschule, where reform pedagogy - ubiquitous at the time in various educational and life reform movements throughout Germany - embraced the study of rhythm. ${ }^{30}$ She went on to study theater with Max Reinhardt, where she cut her first silhouettes, often inspired by characters from Reinhardt's productions. In these early silhouettes, Reiniger experimented with style, accenting bodily gesture through the sinuous curves typical of art nouveau (Abb. 8). ${ }^{31}$

Her first film, created as a member of the Institute for Cultural Research, explored the vivification of silhouettes not only through form but also through the process of stop-motion animation. ${ }^{32}$ The Ornament of the Heart in Love (Das Ornament des verliebten Herzens, 1919) explored the narrative potential of morphing geometries through the frame of a romantic vignette. Delicately cut shapes coalesce, part, and reconvene in various patterns to express the romantic relationship between two protagonists. As their love blooms, dies, and is resurrected through the constant mutation of silhouettes, frame becomes fill, and lovers morph into mise-en-scène and back again. Playful muta-

29 Lotte Reiniger: Moving Silhouettes, in: Film Art, vol. 2, Second Quarter (1936), pp. 14-18, here p. 15.

30 For Reiniger's biography, see Alfred Happ: Lotte Reiniger 1899-1981: Schöpferin einer neuen Silhouettenkunst, Tübingen 2004. Dance historian Susan Manning has pointed out that dance gymnastics (Tanz-Gymnastik) were popular in Germany around the 1920s, and that this interest was indebted equally to modern dance (Ausdruckstanz), sports, and the dawning of a new sphysical culturer. Susan Manning: Ecstasy and the Demon: The Dances of Mary Wigman, Minnesota 2006, p. 8. Germanist Michael Cowan argues that modernity was fundamentally defined by the study of rhythm. He traces a conceptual division between natural and mechanical rhythm, both of which exerted influence - and spawned different legacies - in the new medium of film. Michael Cowan: Technology's Pulse: Essays on Rhythm in German Modernism, London 2011.

31 The orientalist pantomime, Sumurûn, was a staple of Rheinhardt's repertoire. It premiered in 1910 at the Kammerspiele and toured extensively thereafter. See John Louis Styan: Max Reinhardt, Cambridge 1982, pp. 26-28.

32 The Institute for Cultural Research (Institut für Kulturforschung) was an experimental animation studio founded in Berlin in 1919 by Hans Cürlis. Members included Lotte Reiniger, Berthold Bartosch, and Carl Koch, among others. They collaborated with artists such as Walter Ruttmann and Lázló Moholy-Nagy, and were frequently commissioned to create special effects for UFA studio productions. See Werner Biedermann and Lotte Reiniger: Gespräch mit Lotte Reiniger, in: Lotte Reiniger - Silhouettenfilm und Schattentheater, ed. by the Puppentheatermuseum im Münchner Stadtmuseum, Munich 1979, pp. 46-59, here p. 47. Ulrich Döge: Kulturfilm als Aufgabe: Hans Cürlis (1889-1982), Filmblatt-Schriften. Beiträge Zur Filmgeschichte, vol. 4, Berlin 2005. 


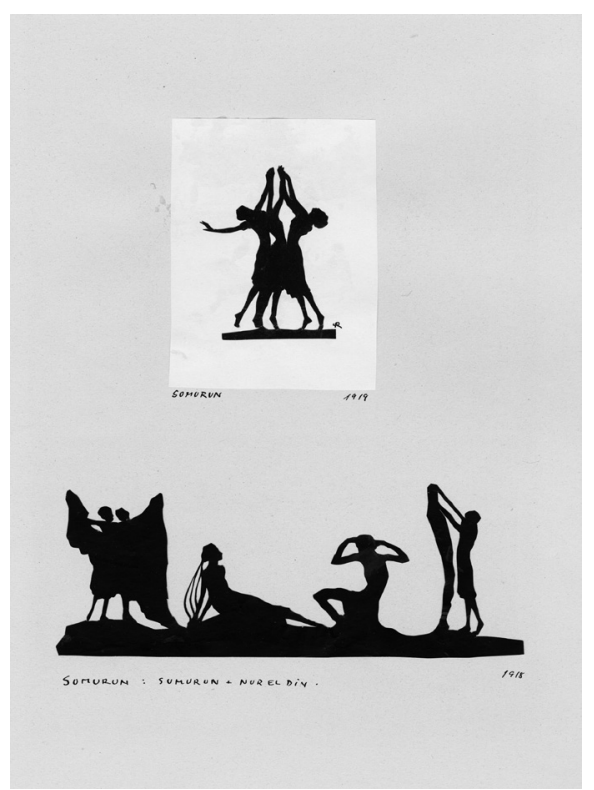

Abb. 8: Lotte Reiniger: Sumurûn silhouettes, 1919, 1918, paper. Stadtmuseum Tübingen, R 1228.

(C) VG Bild-Kunst, Bonn

tions such as these set the stage for Reiniger's life-long investigation into the choreographic possibilities of the decorative in film. ${ }^{33}$

Throughout her career, she repeatedly compared animation to ballet and her essays on the relationship between the two constitute a unique contribution to animation theory. In an essay titled Moving Silhouettes (1936), Reiniger stated: »The creator of trick-film movement can be compared with the choreographer of the ballet - only he has not the space of the stage, but the more flat conditions of the screen to consider. ${ }^{34}$ Flat though they might have been, these conditions contained boundless possibilities for movement. While a stage had depth and height, it also suffered from gravity, a force from which Reiniger's silhouettes were gleefully emancipated:

33 See Katherine Rochester: Animating Ornament in The Adventures of Prince Achmed, in: Evamarie Blattner/Bernd Designer/Matthias Knop/Wiebke Ratzeburg (ed.): Animation und Avantgarde, pp. 117-128.

34 Lotte Reiniger: Moving Silhouettes, p. 15. 
If you draw a line to follow the steps of ballet dancers as they move through the rarefied space of the stage, you create an arabesque of ornaments [...]. Where ballet traces these patterns on a horizontal ground, the screen tilts the whole thing onto a vertical plane. My figures, instead of being depressed by the law of gravity with all its attendant disadvantages, lie flat on the trick table, completely at their ease. My camera, instead of confronting them in the normal way, looks down on them from above. ${ }^{35}$

It was this boundless freedom of movement paired with bold choreography that rendered Reiniger's films so fantastic; for animation provided an arena where choreography could exceed the confines of the stage. In an article titled Film as Ballet (1936), Reiniger explored the differences between theatrical versus filmic movement, reflecting upon the nature of space in each. ${ }^{36}$ She was particularly interested in depth and flatness, and the ways in which ballet might provide a metaphor for choreographing the mechanized space of the screen: "A solo dancer has the possibility of lateral movement; but on stage there is also the possibility of movement in depth and, more important still, a combination of these two movements along the two stage diagonals [...] it is to the cinema's special advantage that its very nature makes it possible to use a unique kind of space-time diagonal.«37 This cinematic diagonal might be as simple as a formulaic chase scene, »in which pursuers and pursued establish the right each to one of the screen's diagonals and the pursuit is cut into short scenes and cross-mounted «. ${ }^{38}$ In such a montage, space would be flattened into horizontals and diagonals while time, exploded by the endless possibilities opened up by editing, would be infinitely malleable.

Reiniger articulated these observations while living in London, where she had moved to prepare a series of solo exhibitions at British museums. Her time there coincided with a rich period in ballet history and she took full advantage of the season. Inspired by Alexandra Danilova and Paul Petroff in W. de Basil's Ballets Russes, and by Alicia Markova and Anton Dolin in the newly formed Markova-Dolin Ballet company, Reiniger applied herself to the intensive study of balletic movement. Her sketchbooks were her constant companion at performances. She filled pages with kinetic pencil studies and even sketched with scissors, thinking through cuts as she snipped pointed toes and gracefully extended arms (Abb. 9).

35 Lotte Reiniger: Film as Ballet, p. 170.

36 See Lotte Reiniger: Moving Shadows.

37 Lotte Reiniger: Film as Ballet, p. 170.

38 Ibid., p. 171. 

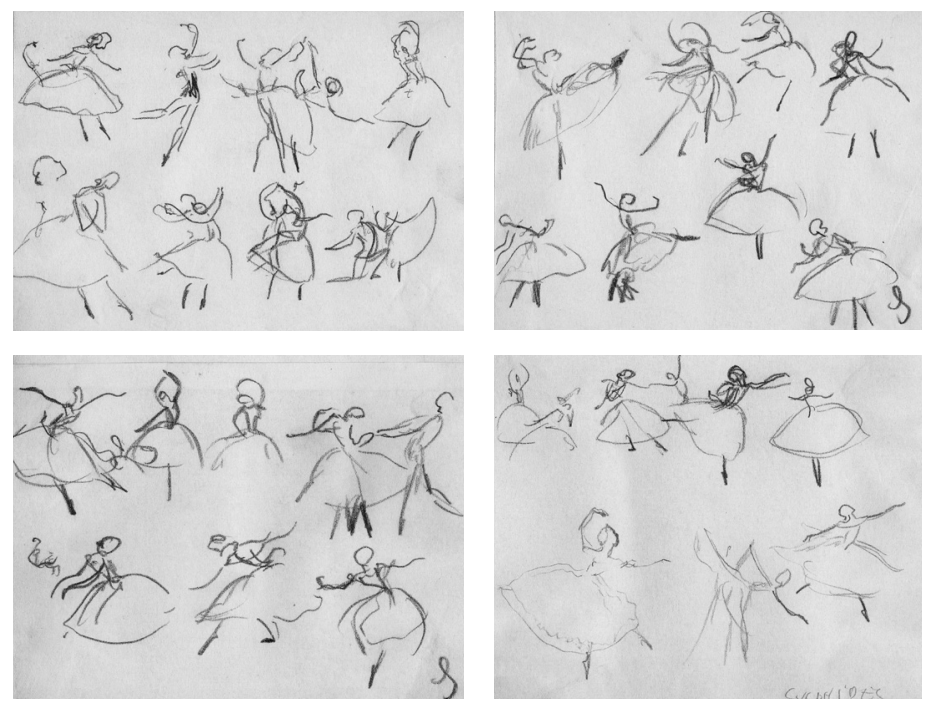

Abb. 9: Lotte Reiniger: Ballet sketches, 1936, graphite on paper. Stadtmuseum Tübingen, R 1301, p. 20. (C) VG Bild-Kunst, Bonn

She was a familiar figure at the theater. Anton Dolin paused to enjoy her work during at least one of his performances and in 1936, Reiniger published a series of silhouettes in tribute to W. de Basil's Ballet Russe (Abb. 10). Working in miniature with black and white figures perched upon a strip of stage, Reiniger's depiction of scenes from Swan Lake, for example, captured the poise and exacting grace of Léonide Massine's famous choreography (Abb. 11). ${ }^{39}$

Reiniger sold her ballet silhouettes in limited edition through J. Kyrle Fletcher, Ltd., who recommended them as "Christmas gifts of originality and distinction" perfect for "all lovers of the ballet« (Abb. 12).

Hoping, perhaps, for a more serious patron, Reiniger gave 17 silhouettes to the Victoria \& Albert Museum, where they are held in the collection today. ${ }^{40}$

39 W. de Basil's Ballet Russes gave fifteen performances of Swan Lake at Covent Garden, London, June-August 1936. The production starred Alexandra Danilova and Paul Petroff with choreography by Léonide Massine. See J.P. Wearing: The London Stage 1930-1939: A Calendar of Productions, Performers, and Personnel, London 2014, p. 533.

40 The Victoria \& Albert Museum holds the following Ballet Russe silhouettes by Lotte Reiniger in its collection, listed here with inventory number: La Boutique Fantasque, S.3672-2013 to S.3678-2013; Le Beau Danube, S.3688-2013; Le Tricome, S.3686-2013f; Good-Humoured Ladies, S.3684-2013; The Firebird, S.3683-2013f.; L'Après-midi d'un faune, S.3679-2013; Les Sylphides, S.3685-2013; Le Carnaval, S.3681-2013; Aurora's Wedding, S.3680-2013. 


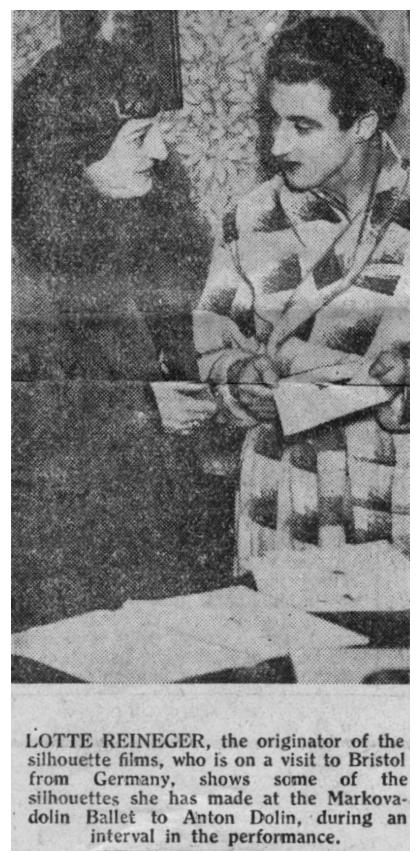

Abb. 10: Lotte Reiniger and Anton Dolin pictured in the Bristol Evening World, 11. October, 1935. Stadtmuseum Tübingen, R 1585. (C) VG Bild-Kunst, Bonn

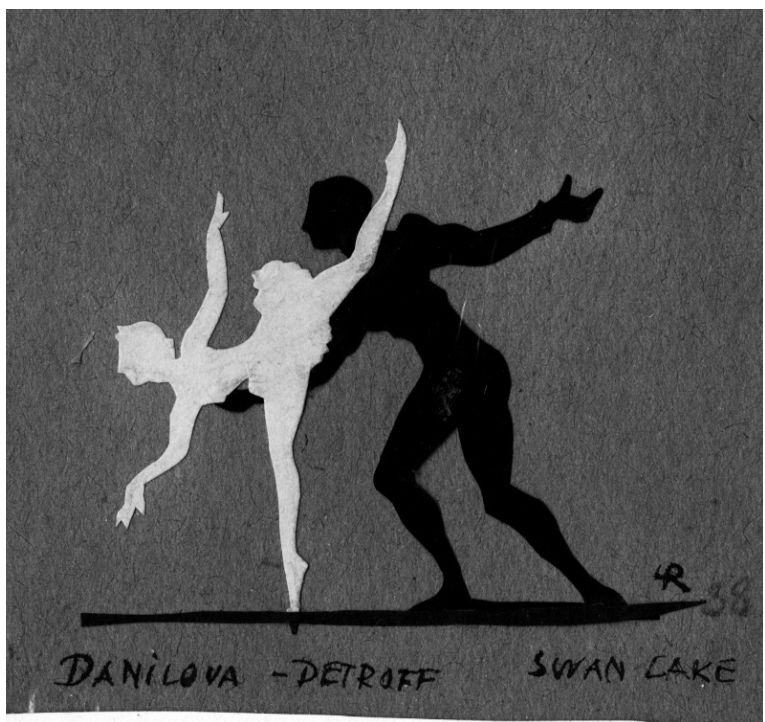

Abb. 11: Lotte Reiniger: Silhouette Figures of Alexandra Danilova and Paul Petroff dancing Swan Lake, 1936, paper. Stadtmuseum Tübingen, R 1309, (C) VG Bild-Kunst, Bonn 


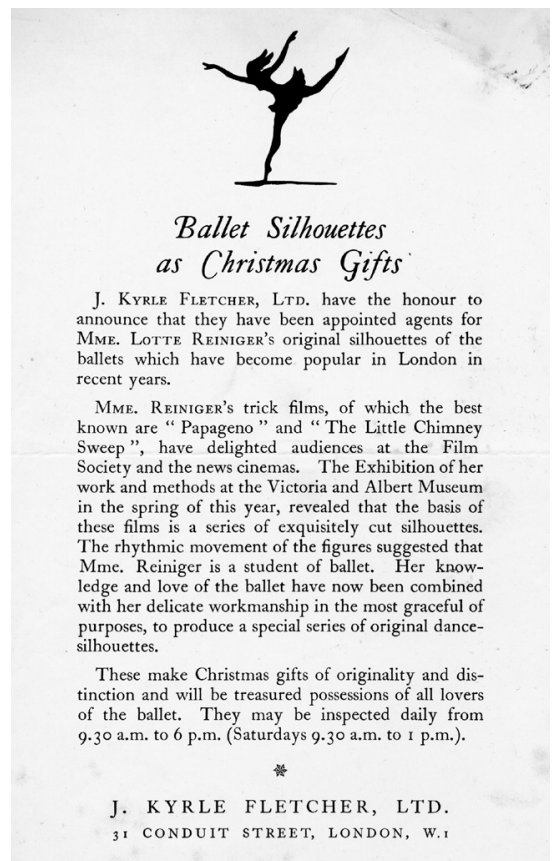

Abb. 12: Kyrle Fletcher, Ltd.: "Ballet Silhouettes as Christmas Gifts, 1936. Stadtmuseum Tübingen, R 1552.

(C) VG Bild-Kunst, Bonn

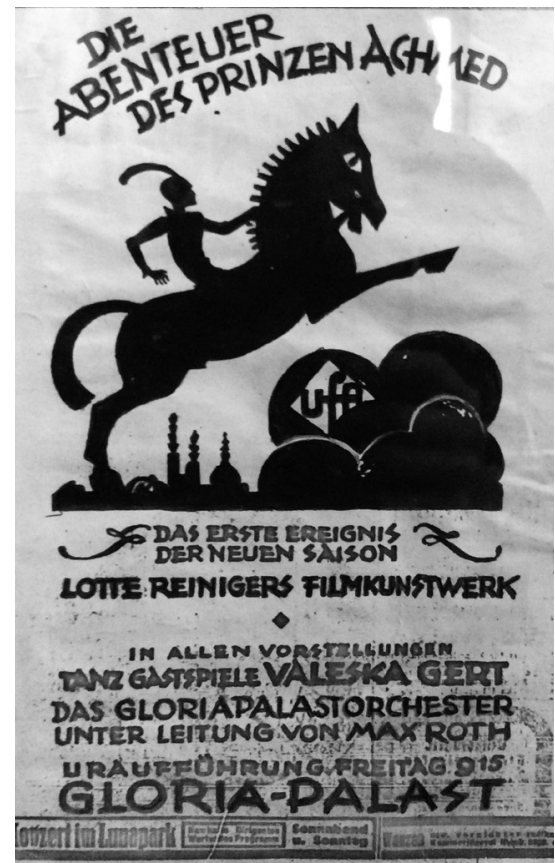

Abb. 13: Berlin newspaper announcement for The Adventures of Prince Achmed at the Gloria - Palast, featuring Valeska Gert as a special guest dancer, 1926. Stadtmuseum Tübingen, R. ㄷ VG Bild-Kunst, Bonn

Long before she went to London, however, Reiniger had already proved a thoroughly original choreographer of dance on film. The Adventures of Prince Achmed with its three year development phase and feature-length presentation, stands as Reiniger's most experimental engagement with dance due to the sheer variety of movement styles it incorporates. Even before the projector rolled at its Berlin screenings, filmgoers were treated to a performance by notorious cabaret dancer Valeska Gert (Abb. 13).

Once the film began, spectators were transported to Baghdad (Abb. 14). In the film's first scene, tiny courtiers march forth from the gates of a sprawling, domed palace. In time to the music (composed for the film by Wolfgang Zeller), they strut in step, forming a triangle whose tip aligns with the royal gates and whose base runs parallel to the bottom of the screen. The royal entourage enters from screen right. At the center of the procession sits the Kalif, installed on a sumptuous dais festooned with feathers. He is flanked 


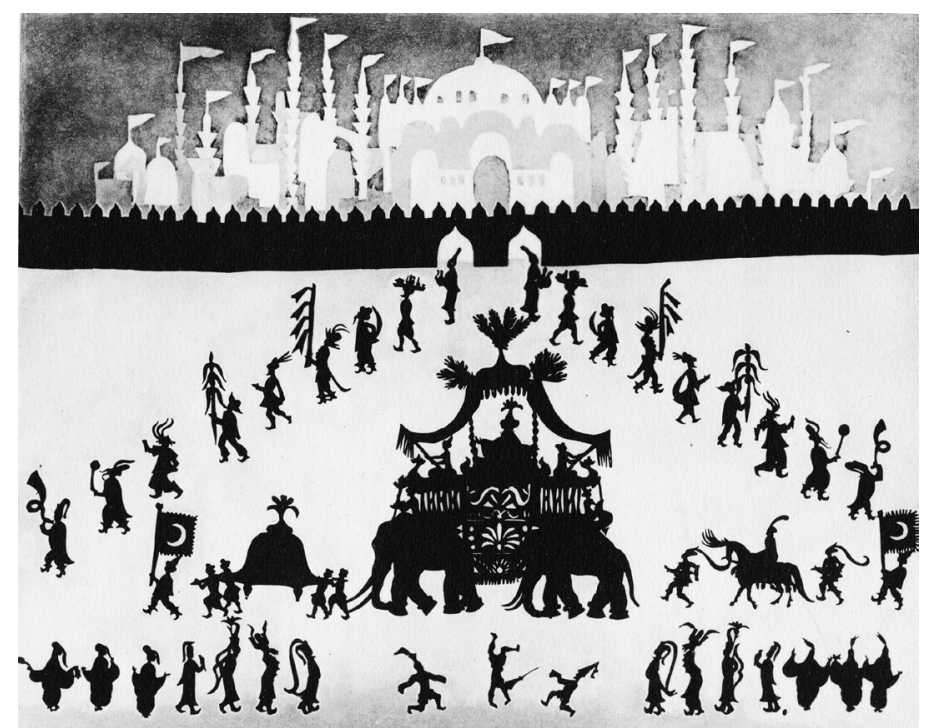

Abb. 14: Lotte Reiniger: The Adventures of Prince Achmed, 1926, film still. Stadtmuseum Tübingen, R 1998-2. (C) Christel Strobel, Agentur für Primrose Film Prod., Munich

by his children, the princess Dinarsarde, whose modest palanquin is held aloft by four footmen, and Prince Achmed, who draws up the rear with his boisterous stallion. The orderly repetition of the minarets in the background is echoed in the measured steps of the actors in the foreground, who move with the sedate comportment of dancers at court. Indeed, the choreography in this scene recalls what dance historian Richard Powers has referred to as the conventions of Renaissance dance wherein "[f]igures traced on the floor had well understood meanings at the time (triangles, spirals, interlocking rings) so that subtle messages could be conveyed through gestures and patterns «. ${ }^{41}$ With scenes such as these, it is no wonder that Reiniger's choreographic eye was appreciated by critics. Typical reviews of Achmed featured accolades that focused on movement. After attending the press screening at the Volksbühne on 2 May 1926, one critic observed:

41 Richard Powers: Dances of the Late Renaissance (16 ${ }^{\text {th }}$ Century), https://socialdance. stanford.edu/Syllabi/late_renaissance.htm (last accessed 15 December 2015). 
The usual hardness of the silhouettes is obviated in the case of this new shadowfilm by the delicacy and grace of the figures, their manifold subtle movements and the richness and variety of the backgrounds which are done in different tones of black or gray and give great depth and distance, as well as a certain sense of reality. The movements of the figures are, of course, as close to human as is possible; but the mere manner of manipulation brings about a certain slowness and dignity of movement, a conventionalization of step or gesture, which lends additional charm to these products of scissors and movie-camera. ${ }^{42}$

As the reviewer notes, movement in Reiniger's work often ranges from naturalistic to highly stylized. Even when characters do not appear to be dancing, they nevertheless often adopt poses that recall well-known pieces from the history of dance. For example, media studies scholar Susanne Marschall has observed that in certain scenes in Achmed, characters are arranged to resemble poses from Vaslav Nijinsky's performance, L'après-midi d'un faune (1912). ${ }^{43} \mathrm{In}$ Reiniger's case these poses - which also resemble Egyptian hieroglyphics in their alignment of a frontally facing body with a head turned in profile - were as much a reference to modern dance as they were an acknowledgement of her fascination with conventions of visual representation from Africa and the Middle East. ${ }^{44}$ Film scholar Antonia Lant has drawn attention to the fact that such interest was widespread in the early years of cinema: „Egypt, and what it came to mean in the century between Champollion's unlocking of the Rosetta stone in 1822 and the coming of sound to cinema in the late 1920s, provided a means of explaining, legitimating, but above all conceptualizing the new motion picture medium. «5 $^{4}$ Although Reiniger certainly shared in what Lant has called early cinema's "Egyptomania«, visible in everything from the plots of orientalist romps to the architectural ornamentation of the theaters in which they played, Reiniger's interest in Egypt was also technical. She credited Egyptian art for helping her solve certain problems of movement and expression that arose in the form of the animated silhouette.

42 Herman George Scheffauer: Arabian Nights' Story Lives Again in Striking Two Dimensional Picture (1926). Newspaper clipping, Lotte Reiniger Nachlass, Stadtmuseum Tübingen, R 646.

43 See Susanne Marschall: Bewegung(en) auf dem Tricktisch. Lotte Reinigers Metamorphosen und Tänze im Kontext der Avantgarde/ Movement(s) on the Animation Table: Lotte Reiniger's Metamorphoses and Dances in the Context of the Avant-Garde, in: Evamarie Blattner/Bernd Designer/Matthias Knop/Wiebke Ratzeburg (ed.): Animation and Avantgarde, pp. 55-70, here p. 67.

45 Antonia Lant: The Curse of the Pharaoh, or How Cinema Contracted Egyptomania, in: October 59 (1 January 1992), pp. 87-112, here p. 90. 
Egyptian reliefs, in particular, were a model for suggesting affect within the strictures of stylized form: »They let the feet move sideways, but they show the two shoulders, and that shows the two arms with them, greatly widening their field of expression. «46

But Reiniger was concerned with neither naturalistic representation nor conventional ornament alone. In Achmed, she delighted equally in choreography that highlighted the fantastic potential of animated bodies. Although the pliability of space, time, and bodies in animated film attracted the attention of heavy-weight theorists such as Sergei Eisenstein, Walter Benjamin and Theodor Adorno throughout the 1930s and 1940s, their influential arguments centered solely on Disney and the corpus of line-drawn animation. ${ }^{47}$ Concepts such as Eisenstein's "plasmatic«, coined to describe the continual stretching and springing that Mickey Mouse exhibits in the Silly Symphonies, frequently fail to grasp the quality of change in Reiniger's silhouetted, stopmotion work. Indeed, a more convincing - if largely forgotten - model for metamorphosis in the trick film may be found in a lecture delivered by one of Reiniger's closest mentors. In 1916, actor and director Paul Wegener spoke on The Artistic Possibilities of Film, urging his audience to consider the boundless creative potential of animation. Through the manipulation of specially built models and moveable puppets, Wegener declared that filmmakers might »bring us into a whole new pictorial fantasy world, as in a magic forest, and arrive in the domain of pure kinesthesis, of optical lyricism « ${ }^{48} \mathrm{He}$ went on to imagine an animated sequence driven less by the distortion of bodies than by their miraculous transformation into other forms: "A vast empty surface. Suddenly, mighty lilies grow up from below, the lilies bloom, their

46 Lotte Reiniger: Shadow Puppets, Shadow Theatres, and Shadow Films, Boston 1975, p. 48.

47 See Sergei Eisenstein: Eisenstein on Disney (1941), ed. by Jay Leyda, London 1988. Benjamin included a discussion of Mickey Mouse in the first (1935) and second (1936) versions of his canonical Work of Art-essay. The passages on Disney were later edited out of the third and final version (1938/39). See Walter Benjamin: The Work of Art in the Age of Its Technological Reproducibility [First Version], translated by Michael W. Jennings, in: Grey Room 39 (Spring 2010), pp. 11-37. See also Miriam Hansen: Of Mice and Ducks: Benjamin and Adorno on Disney, in: South Atlantic Quarterly 92/1 (Winter 1993), pp. 27-61.

48 "So treten wir in eine ganz neue bildliche Phantasiewelt wie in einen Zauberwald ein und kommen zu dem Gebiet der reinen Kinetik, der optischen Lyrik«. Paul Wegener: Die künstlerischen Möglichkeiten des Films, in: Paul Wegener: Sein Leben und Seine Rollen: Ein Buch von ihm und über ihn, ed. by Kai Möller, Hamburg 1954, pp. 102-113, here p. 112 . 
leaves, flickering in the air, gradually become flames, the flames give off thick smoke, the smoke transforms itself into heavy clouds", and so on until the screen becomes" [a] splendid, animated surface ${ }^{49}$ Reiniger attended the lecture and she often credited Wegener's vision for igniting her own. Uniting these early epiphanies with dance, Reiniger devised a potent strategy for filming the fantastic by drawing on a discipline whose strategies for rendering the body expressive had rarely been combined with animation.

In Achmed, the defining battle between the sorcerer and the witch is a tour de force dance that presents an array of possibilities for magical - and animated - transformation. The scene opens on a barren mountaintop. The good witch, adorned with the spiky amulets of her trade, begins a rhythmical incantation to summon the evil magician. She rocks from foot to foot, emitting powerful orbs of light which sail from her body in ever widening circles. The magician answers. He appears gradually, hunched back and hooked hands shimmering into focus through a marbled curtain of iridescent slime. The witch lunges towards him but he evades her grasp, assuming the shape of a lion, crouching in preparation for attack. But as the lion pounces, the witch recoils, morphing into a snake. Caught in her fangs, the lion contracts, instantly unfurling as a fearsome scorpion, while the snake winds herself up and springs back at the scorpion in the shape of a fighting cock. And so the battle progresses, shape after shape, beast after beast, tangling with each other in a fearsome dance that unites the magic of sorcery with the transformational power of stop-motion animation.

\section{From Abstract Principles to Materialized Bodies}

If Lavater substantiated the philosophy of physiognomy with silhouettes, and Balázs developed a theory of physiognomy without them, then we might say that Reiniger transformed physiognomy into choreography. Her animations are studies in pulsing rhythm, contributions to the larger project of investigating the effects of mechanization on the human body in an era transformed by the advent of technology in everyday life. While Lavater had championed the pure distillation - or abstraction - of the human character

49 »Eine weite leere Fläche. Plötzlich wachsen vom unteren Rande mächtige Lilien auf, die Lilien blühen auf, die Blätter züngeln in die Höhe, werden allmählich zu Flammen, die Flammen geben einen dicken Rauch, der Rauch wandelt sich zur schweren Wolke... Eine prachtvoll belebte Fläche« (ibid., pp. 112-113). 
into the form of the silhouette, Reiniger enacted the total corporealization of the silhouette into a moving actor. In 1926, she gave an interview to a Berlin newspaper, in which she described the process of transforming the prince she found in the book, The Thousand and One Nights, into the title character for her film, The Adventures of Prince Achmed:

[...] my Prince had to be reborn in a more thorough fashion than is usually necessary in such cases. The problem could not be solved by merely writing a scenario to suit him and then entrusting the part to some film-actor. My Prince had to be invented bodily, he had to be designed, cut out, wired, illuminated, moved, and photographed [...]. I silhouetted him. And then I sbuilt him - out of cardboard, wire and thin sheet-lead, so that he might fulfill all his functions in the shadow-play in a natural and convincing manner. I articulated him, gave him a moveable head, neck, shoulders, chest, abdomen, hips, legs, upper and lower arms, knees, hands and feet, fastened these together with hinges and pivots and then hammered and rolled him until he became a real, living figure for a shadow film. ${ }^{50}$

The materiality invoked in this passage is stunning. Drawing attention to the crucial difference between ssilhouetting ‘ and `building , Reiniger describes the material conditions that informed her own laboring body in the creation of Achmed's. What emerges is a Genesis story equal to Lavater's. While Schellenberg's etching depicts woman as the mute object of physiognomic study, Reiniger instates herself as an active creator. The silhouette that Lavater wished to still springs back into motion under Reiniger's scissors. For if the outline signifies the human abstracted, then Reiniger gives the silhouette back its humanity, filming it into motion through the life-giving cuts of animation itself.

50 Lotte Reiniger quoted in: Herman George Scheffauer: Arabian Nights' Story Lives Again in Striking Two Dimensional Picture (1926). Newspaper clipping, Lotte Reiniger Nachlass, Stadtmuseum Tübingen, R 646. 